\title{
CXCR4 expression on circulating pan-cytokeratin positive cells is associated with survival in patients with advanced non-small cell lung cancer
}

\author{
Karen L Reckamp*1,2, Robert A Figlin1, Marie D Burdick³, \\ Steven M Dubinett ${ }^{4,5}$, Robert M Elashoff ${ }^{6}$ and Robert M Strieter ${ }^{3}$
}

\begin{abstract}
Address: ${ }^{1}$ Department of Medical Oncology \& Therapeutics Research, City of Hope and Beckman Research Institute, Duarte, USA, ${ }^{2}$ Department of Hematology \& Hematopoeitic Transplantation Medicine, City of Hope and Beckman Research Institute, Duarte, USA, ${ }^{3}$ Department of Medicine, University of Virginia School of Medicine, Charlottesville, USA, ${ }^{4}$ Division of Pulmonary and Critical Care Medicine, David Geffen School of Medicine at UCLA, Los Angeles, USA, ${ }^{5}$ Department of Pathology and Laboratory Medicine, David Geffen School of Medicine at UCLA, Los Angeles, USA and ' Department of Biomathematics, David Geffen School of Medicine at UCLA, Los Angeles, USA
\end{abstract}

Email: Karen L Reckamp* - kreckamp@coh.org; Robert A Figlin - rfigiln@coh.org; Marie D Burdick - mdb5b@virginia.edu; Steven M Dubinett - sdubinett@mednet.ucla.edu; Robert M Elashoff - relashof@biomath.ucla.edu;

Robert M Strieter - RMS4W@hscmail.mcc.virginia.edu

* Corresponding author

Published: 29 June 2009

BMC Cancer 2009, 9:213 doi:10.1186/147|-2407-9-2/3

This article is available from: http://www.biomedcentral.com/I47I-2407/9/213

(C) 2009 Reckamp et al; licensee BioMed Central Ltd.

This is an Open Access article distributed under the terms of the Creative Commons Attribution License (http://creativecommons.org/licenses/by/2.0), which permits unrestricted use, distribution, and reproduction in any medium, provided the original work is properly cited.

\begin{abstract}
Background: The CXC chemokine, CXCLI2, and its receptor, CXCR4 promote metastases of a variety of solid tumors, including non-small cell lung cancer (NSCLC). The expression of CXCR4 on tumor cells may represent a critical biomarker for their propensity to metastasize. This study was performed to evaluate the hypothesis that co-expression of pan-cytokeratin and CXCR4 may be a prognostic marker for patients with advanced NSCLC.
\end{abstract}

Methods: We evaluated CXCR4 levels on circulating pan-cytokeratin positive cells from patients with NSCLC. NSCLC tumor and metastases were also assessed for the presence of CXCR4.

Results: Pan-cytokeratin positive cells were increased in the circulation of patients with NSCLC, as compared to normal control subjects. Patients with pan-cytokeratin $+/$ CXCR4 $+=2,500$ cells/ $\mathrm{ml}$ had a significant improvement in median survival when compared with patients with pancytokeratin $+/$ CXCR4 $+>2,500$ cells/ml (not achieved versus 14 weeks). CXCR4 expression was found on NSCLC tumors and at sites of tumor metastasis.

Conclusion: This study suggests that CXCR4 may be a prognostic marker in NSCLC, and provides hypothesis-generating results, which may be important in determining metastatic potential. In future studies, we will prospectively evaluate the prognostic significance of pancytokeratin/CXCR4+ cells, and determine the mechanisms involved in the regulation of CXCR4 expression on tumor cells in a larger patient population. 


\section{Background}

Approximately 213,380 new cases of lung cancer will be diagnosed and 160,390 deaths will occur from lung cancer during 2007. Lung cancer is the leading cause of cancer death among both men and women in the United States [1]. Nearly $60 \%$ of those diagnosed with lung cancer die within one year of their diagnosis, and the five-year survival for all patients with lung cancer is only $16 \%$. This statistic has not improved significantly in the past 10 years. Surgical resection offers the most promising chance for cure in patients who present with early-stage disease, although the majority of patients will develop recurrence despite complete surgical resection. This is likely secondary to undetected microscopic metastatic disease at the time of surgery, and recently adjuvant chemotherapy has been shown to improve survival in some early-stage patients [2-4]. Identification of targeted treatments for micrometastatic disease could block tumor cell migration and improve outcomes in this devastating disease.

Cytokeratins have been identified as potential markers for the detection of circulating cancer cells by RT-PCR, flow cytometry and RT-PCR [5-7]. Cytokeratin 19 has been described in the serum of patients with non-small cell lung cancer (NSCLC), and has been associated with tumor burden and response to therapy $[7,8]$. However, cytokeratins can be expressed in low levels in peripheral blood mononuclear cells, which limits the utility of this biomarker to accurately detect circulating micrometastatic disease.

Chemokines within the tumor microenvironment, and at sites of metastases can mediate invasion of tumor cells through mechanisms similar to those used in leukocyte stem cell trafficking [9]. Chemokines are a family of 8-11 $\mathrm{kd}$ proteins, subdivided on the basis of the position of the $\mathrm{N}$-terminus cysteine residues. They are involved in leukocyte chemotaxis and activation, and have been associated with the regulation of angiogenesis and tumor cell invasion [10-12]. Chemokine receptors are seven transmembrane, G protein-coupled receptors, and are expressed on leukocytes, endothelial cells, stromal cells, epithelial cells and tumor cells $[13,14]$. Chemokine gradients within the tumor microenvironment and target organs can determine the metastatic potential of a tumor [15].

CXCR4 has been the major chemokine receptor expressed on cancer cells [16-20]. Its ligand, CXCL12 is essential for the homing of hematopoeitic stem cells during embryogenesis and adult life [21,22]. Müller and colleagues provided initial evidence linking CXCL12/CXCR4 biological axis to breast cancer metastasis to specific organs [16], which was confirmed in non-small lung cancer [20]. More recent studies have suggested that CXCR4 is expressed on various other cancer cells and its expression stimulated migration of cancer cells towards a CXCL12 gradient established in specific target organs for metastases [1719]. The CXCR4/CXCL12 biological axis has been postulated to have an important in supporting cancer stem cells [23]. These findings suggest that CXCL12/CXCR4 may be a critical determinant for the metastatic potential of NSCLC, and supports the notion that the magnitude of pan-cytokeratin+ circulating cells that express CXCR4 will correlate with survival of patients with NSCLC. In this study we tested this hypothesis and found that the magnitude of circulating pan-cytokeratin+/CXCR4+ cells in patients with NSCLC was directly correlated with worse prognosis, and that these findings could be used as a foundation for future prospective biomarker studies. Furthermore, these results support the contention that further understanding the molecular mechanisms that are involved in the regulation of CXCR4 expression on tumor cells could lead to potential targets to modify the expression of CXCR4 on NSCLC cells and impact on metastases.

\section{Methods}

\section{Study Design}

Sixteen subjects with NSCLC and 10 normal healthy donors seen at UCLA Medical Center between October 2004 and March 2006 were enrolled. The UCLA institutional review board approved this study protocol, and all patients provided written informed consent. Peripheral blood was collected from patients prior to initiating systemic therapy.

\section{FACS analysis}

Each specimen was processed to isolate buffy coat leukocyte populations for intracellular staining and FACS analysis. Briefly, buffy coat was isolated, red blood cells lysed, and the cells stained with APC anti-CXCR4 (R\&D systems, Minneapolis, $\mathrm{MN}$ ) or isotype control. Cells were then permeabilized with a BD Cytofix/Cytoperm kit (BD Biosciences) and stained with PE anti-Pan-cytokeratin (BD Biosciences). Samples were analyzed on a FACSCalibur instrument using Cellquest 3.2.1f1 software (BD Biosciences).

\section{Immunohistochemistry}

Paraffin-embedded tissue microarrays (Lung: cancermetastasis-normal) were purchased from Imgenex Corp. (San Diego, CA). The arrays were processed for immunohistochemical localization of CXCR4, using monoclonal anti-human CXCR4 antibodies or IgG2b antibodies for negative control (R\&D Systems) as using Vector Elite Kit (Vector Laboratories, Burlingame, California, USA) as described previously [24]. Briefly, the tissue array was incubated with a 1:1 mixture of $3 \%$ hydrogen peroxide in methanol. The array was then exposed to Power Block (BioGenex Laboratories, San Ramon, California, USA) for 30 minutes and, after washing in PBS, stained with 
CXCR4 antibodies or an isotype control antibody for 30 minutes at room temperature. After incubation with the primary $\mathrm{Ab}$, the array was then exposed to a biotinylated anti-mouse secondary $\mathrm{Ab}$ for 30 minutes. The array was washed in PBS and avidin-binding complex (Vector Laboratories) reagent was added, and the array incubated again for 30 minutes. The array was then exposed to the chromogen 3,3'-diaminobenzidine tetrahydrochloride (Vector Laboratories), which turns the positively staining cells brown. Finally, the array was counterstained with hematoxylin and cover-slipped.

\section{Statistical Analysis}

Data were analyzed on a Dell PC computer using SAS version 9.2 XP_PRO platform. Non parametric Kruskal-Wallis test was used to detect the group differences because of small sample size. A survival curve was estimated accord- ing to the Kaplan-Meier method and groups compared with the log rank test. A p-value $=0.05$ was considered significant.

\section{Results}

CXCR4 is Markedly Expressed on NSCLC Primary Tumor and in Cells of Metastatic Lesions from NSCLC tissue microarrays

Immunostaining for CXCR4 expression on these NSCLC tissue microarrays confirmed significant expression of CXCR4 on both tumor cells of primary tumors (Figure 1A and $1 \mathrm{~B}$ ) and metastatic lesions (Figure $1 \mathrm{D}$ and $1 \mathrm{E}$ ). CXCR4 is expressed on a majority $(>80 \%)$ of the tumor cells in either adenocarcinoma or squamous cell carcinoma lung tumor specimens (Figure $1 \mathrm{~A}$ and $1 \mathrm{~B}$, respectively). All of the squamous cell carcinoma or adenocarcinoma lung tumor specimens examined
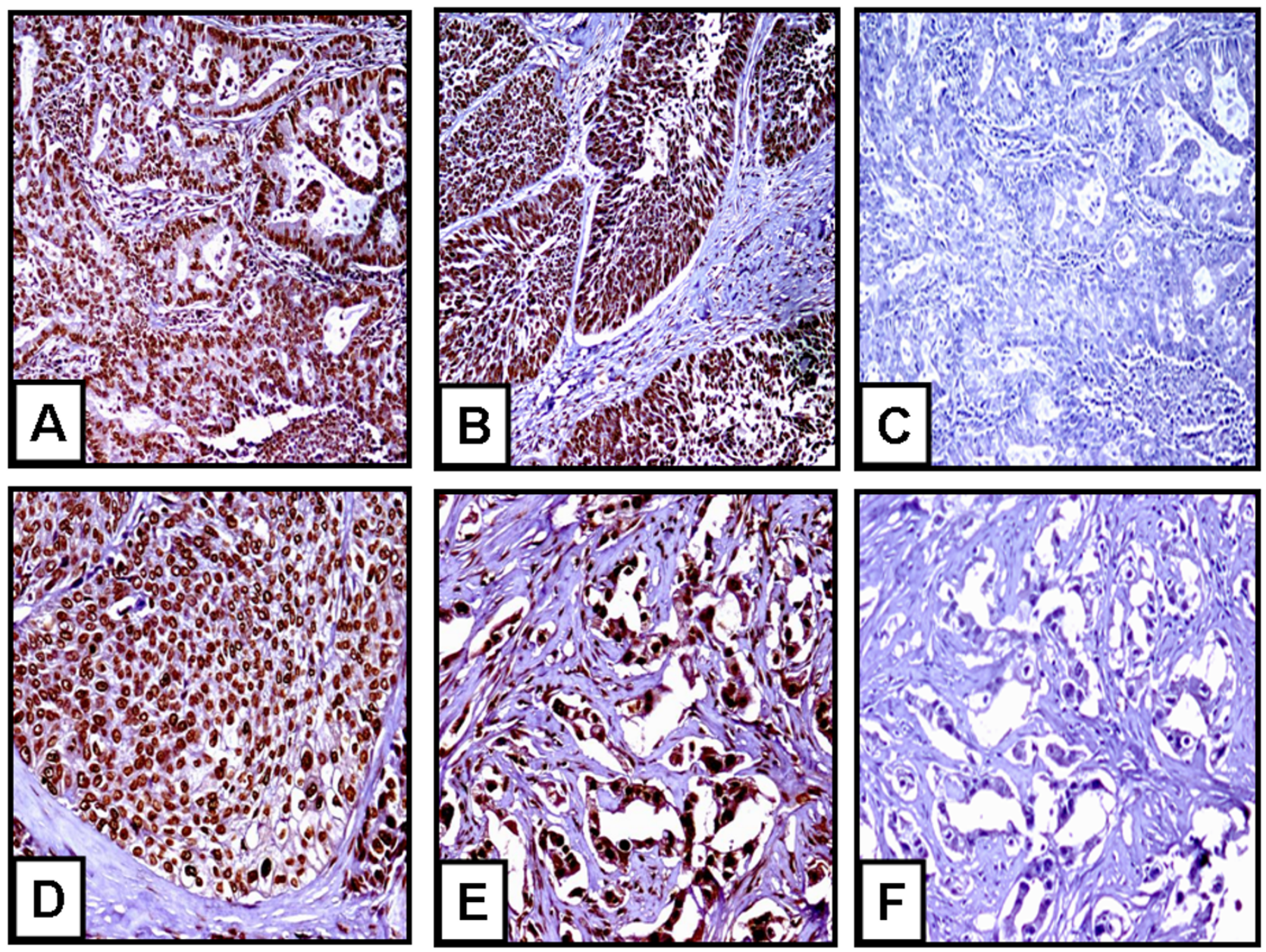

Figure I

CXCR4 expression on both tumor cells of primary tumors and metastatic lesions. A) adenocarcinoma, B) squamous cell carcinoma, C) adenocarcinoma (negative control), D) lymph node metastasis, E) bone metastasis, and F) bone metastasis (negative control). Magnification is at $100 \times$ for A-C and $200 \times$ for D-F. 
expressed positive staining for CXCR4. There was no evidence for non-specific staining with the control antibody (Figure 1C and 1F). In addition, there was little evidence of CXCR4 immunolocalization on host responding cells, such as tumor-associated macrophages, fibroblasts and endothelial cells (Figure 1). Moreover, we found that the expression of CXCR4 was a significant biomarker of metastatic NSCLC in various tissues (Figure 1D and 1E). In contrast, we found no difference in protein levels of CXCL12 in NSCLC tumors (squamous cell carcinoma and adenocarcinoma), as compared to normal lung tissue (data not shown).

\section{CXCR4 Expression and Pan-cytokeratin levels are Elevated in Blood of Patients with NSCLC}

Patient Characteristics

Sixteen patients with NSCLC were enrolled to this study for the analysis of CXCR4 and pan-cytokeratin expression on circulating tumor cells. Eight females and eight males with an average age of 69 years were studied. Two patients had stage IA NSCLC, one had stage IIIA, one had stage IIIB and twelve had stage IV disease. Fourteen patients had been previously untreated and 2 subjects received 1 prior systemic treatment for metastatic disease. Only 2 patients had never smoked in this group (Table 1). The median survival for the group was 60 weeks, (range 6-not reached).

Table I: Patient Characteristics

\begin{tabular}{|c|c|c|c|}
\hline & $\begin{array}{l}\text { All patients } \\
(\mathrm{N}=16)\end{array}$ & $\begin{array}{c}\text { Low risk group } \\
(\text { CXCR4 } \leq 2500 \text { cells } / \mathrm{ml}) \\
(\mathrm{n}=\mathrm{II})\end{array}$ & $\begin{array}{c}\text { High risk group } \\
\text { (CXCR4 > 2500 cells/ml) } \\
(\mathrm{n}=5)\end{array}$ \\
\hline \multicolumn{4}{|l|}{ Gender } \\
\hline $\mathrm{F}$ & 8 & 5 & 3 \\
\hline$M$ & 8 & 6 & 2 \\
\hline \multicolumn{4}{|l|}{ Age } \\
\hline Mean \pm SD & $69 \pm 10$ & $67 \pm 11$ & $74 \pm 6$ \\
\hline Min-max, median & $42-83,73$ & $42-79,70$ & $67-83,73$ \\
\hline \multicolumn{4}{|l|}{ Stage } \\
\hline IA & 2 & 2 & 0 \\
\hline IIIA & I & 0 & 1 \\
\hline IIIB & 1 & I & 0 \\
\hline IV & 12 & 8 & 4 \\
\hline \multicolumn{4}{|l|}{ ECOG PS } \\
\hline 0 & 10 & 7 & 3 \\
\hline 1 & 6 & 4 & 2 \\
\hline \multicolumn{4}{|l|}{ Histology } \\
\hline Adenocarcinoma & 6 & 4 & 2 \\
\hline Large cell & I & 0 & 1 \\
\hline Squamous cell & 2 & 1 & 1 \\
\hline Not Specified & 7 & 6 & 1 \\
\hline \multicolumn{4}{|l|}{ Tobacco (pack-years) } \\
\hline 0 & 2 & 2 & 0 \\
\hline $\mathrm{I}-20$ & 4 & 3 & 1 \\
\hline$>20$ & 10 & 6 & 4 \\
\hline \multicolumn{4}{|l|}{ \# of prior treatments } \\
\hline 0 & 14 & 9 & 5 \\
\hline 1 & 2 & 2 & 0 \\
\hline Mean Survival (weeks) & $65 \pm 50$ & $79 \pm 46$ & $34 \pm 50$ \\
\hline Median Survival (weeks) & 60 (6-NA) & NA (I5-NA) & $14(6-N A)^{*}$ \\
\hline
\end{tabular}

NA, not achieved

$*_{p}=0.03$ and hazard ratio of $0.23(95 \% \mathrm{Cl}, 0.02-0.79)$ for median survival of low risk group versus high risk group (log-rank test). 
CXCR4 and Pan-cytokeratin Expression in Peripheral Blood

We hypothesized that CXCR4 and cytokeratin would be increased on circulating cells of patients with NSCLC. To determine CXCR4 expression on mononuclear cells expressing pan-cytokeratin, we measured human cytokeratin 14, 15, 16, and 19 (pan-cytokeratin) along with CXCR4 on peripheral blood mononuclear cells (PBMC) by FACS in 16 NSCLC patients and 10 normal controls. CXCR4 and pan-cytokeratin expression was elevated on circulating cells of patients with NSCLC. We found pancytokeratin expression was significantly increased $(\mathrm{p}=$ 0.02) on PBMC of patients with NSCLC when compared to normal controls (Figure 2). Combined pan-cytokera-
tin/CXCR4 expression was increased in patients with NSCLC, but the result was not significant $(\mathrm{p}=0.11)$.

Low Circulating CXCR4 and Pan-cytokeratin Expression Predicts for Improved Survival

CXCR4 was elevated on circulating pan-cytokeratin positive cells in sixteen patients with NSCLC (Figure 3). In these patients, we evaluated survival based on co-expression of pan-cytokeratin and CXCR4. Using a cut point of 2500 CXCR4 positive cells/ml, we found a significant improvement in overall survival for patients with low circulating pan-cytokeratin/CXCR4-positive cells when compared to patients with high levels of circulating pancytokeratin/CXCR4-positive cells $(\mathrm{p}=0.03)$ (Table 1$)$.

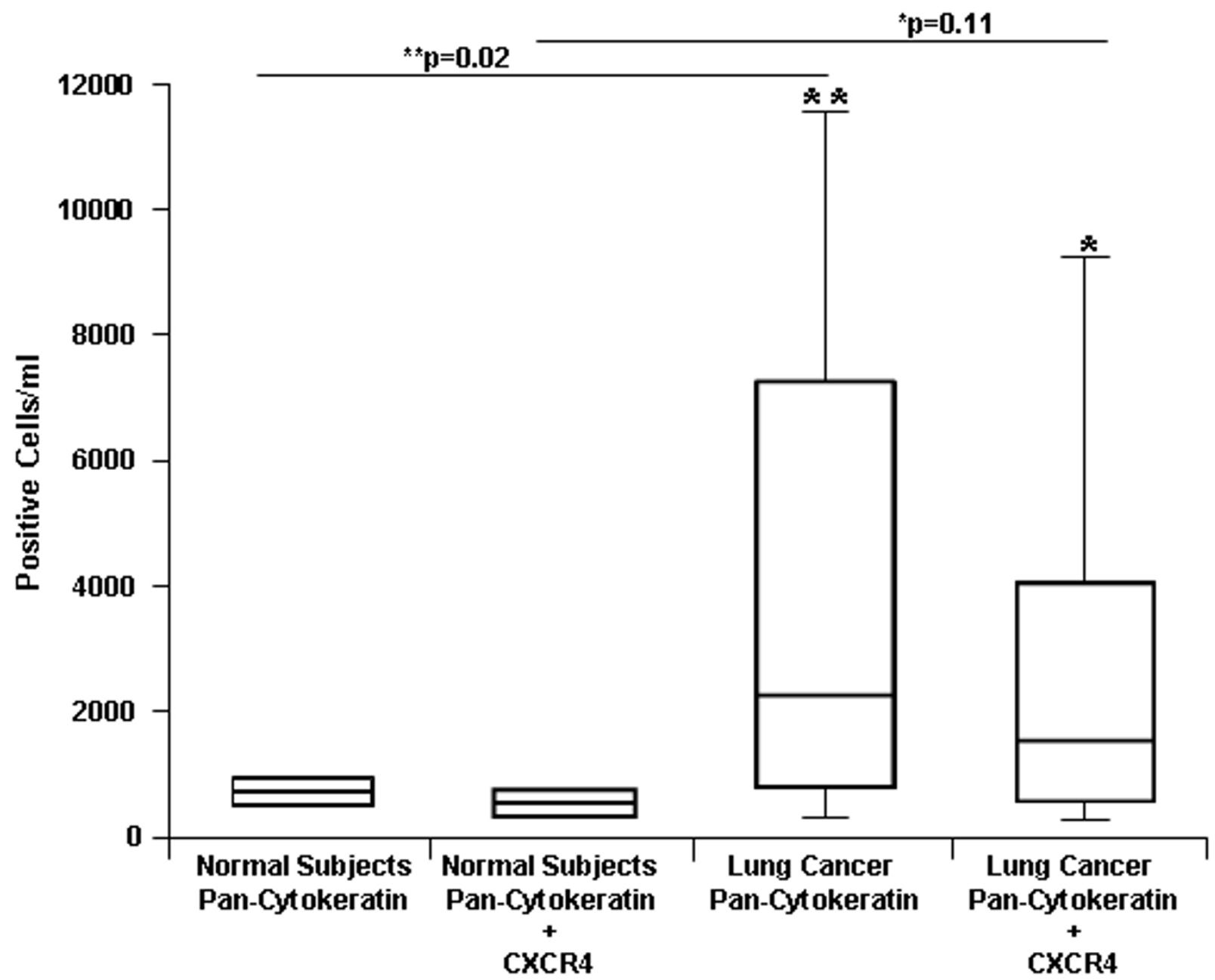

Figure 2

Circulating pan-cytokeratin positive cells and CXCR4/pan-cytokeratin positive cells in I6 patients with NSCLC and 10 normal subjects. CXCR4 and pan-cytokeratin were measured by FACS from normal healthy donors or patients with NSCLC $\left({ }^{*} p=0.11, *^{*} p=0.02\right)$. Horizontal line represents mean. 


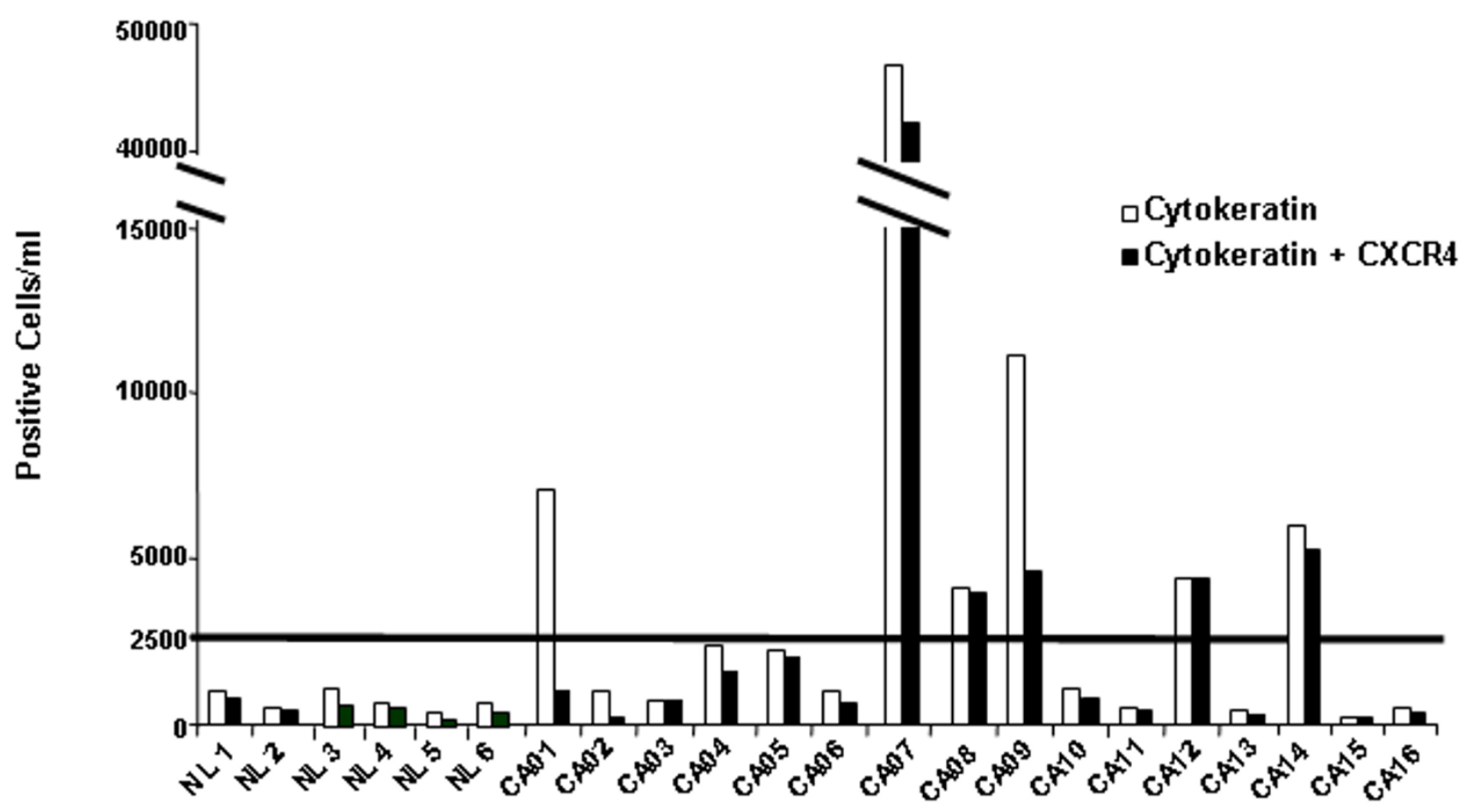

Figure 3

CXCR4 expression on circulating pan-cytokeratin positive cells in patients with NSCLC. Individual patient data for CXCR4 and pan-cytokeratin-these were measured by FACS from normal healthy donors (NL) or patients with NSCLC (CA). Results from six representative normal healthy donors are provided.

Despite the small sample size, the hazard ratio for survival in the group with low expression of pan-cytokeratin/ CXCR4-positive cells was 0.23 (95\% confidence interval (CI), 0.02-0.79). The median overall survival (OS) for patients with NSCLC who had low levels of CXCR4 expression on MNC $(\leq 2500$ CXCR4 positive cells/ml) was not reached versus a median OS of 14 weeks for those with a CXCR4 expression level > 2500 CXCR4 positive cells/ml (Figure 4).

\section{Discussion}

The microenvironment and receptor signaling of the tumor plays a role in promoting the expression of genes that may be relevant in promoting tumor metastases. Chemokines are a group of homologous, yet functionally pleiotropic proteins that directly mediate cell migration and activation and play a role in regulating angiogenesis and metastases [25]. The CXC chemokine, CXCL12, and its receptor, CXCR4 promote metastases of a variety of solid tumors including non-small cell lung cancer (NSCLC) $[9,16,20,26]$. In a human NSCLC SCID mouse chimera, neoplastic cells at secondary metastatic sites significantly upregulate CXCR4 [26]. Furthermore, CXCL12, the ligand for CXCR4, has been shown to be maximally expressed in the organs of metastasis in both lung and breast cancers $[9,16]$. This concept supports the notion that expression of CXCR4 on tumor cells may represent a critical biomarker for their propensity to metastasize. This study was performed to evaluate the hypothesis that CXCR4 may be a marker for circulating tumor cells in metastatic NSCLC.

CXCR4 may play a role in the transition of a tumor from non-metastatic to its malignant phenotype [27]. In this study, we demonstrated that CXCR4 is expressed on primary lung tumors as well as metastatic lesions. This is consistent with previous findings that elevated levels of CXCR4 expression in NSCLC tumors was associated with clinical metastases [28]. Moreover, CXCR4 expression in squamous cell carcinoma of the head and neck could be used to identify tumor cells with increased metastatic potential [29]. Thus, identifying cells with increased CXCR4 expression may be useful to predict the metastatic potential of a tumor and provides a mechanism for inhibiting tumor progression. 


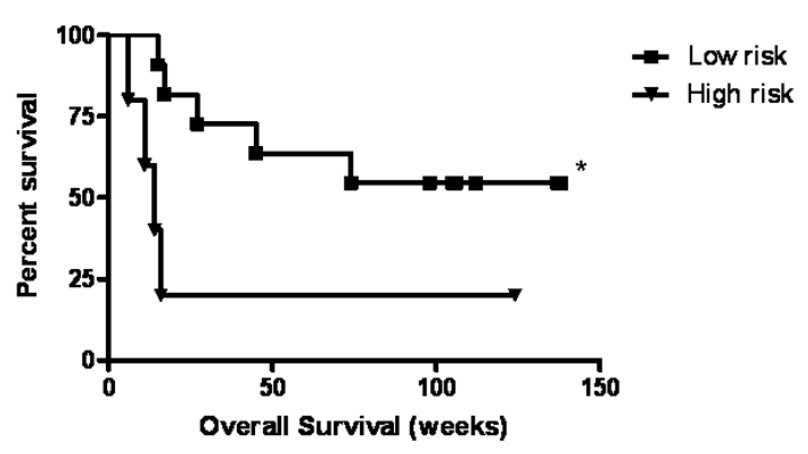

Figure 4

Survival by CXCR4 levels, $\leq 2500$ cells/ml (low risk group, black square) vs. $>\mathbf{2 5 0 0}$ cells $/ \mathrm{ml}$ (high risk group, black triangle) $(* p=0.03)$.

We also demonstrate that circulating pan-cytokeratin and CXCR4 positive cells are more prevalent in patients with NSCLC than normal subjects. Circulating pan-cytokeratin cells were significantly elevated in NSCLC patient when compared to normal subjects. When evaluating pancytokeratin and CXCR4 positive together, we saw a trend toward increased levels of CXCR4 expression in NSCLC patients, but this was not statistically significant. The reasons for this observation may be due to our limited sample size since the pool of circulating CXCR4 positive cells may represent cancer stem cells[9] and comprise a smaller proportion of the cells. Similar findings have been described in metastatic renal cell carcinoma (RCC). Pan, et al. demonstrated that CXCR4 expression was markedly increased on circulating pan-cytokeratin+ cells of patients with metastatic RCC, as compared to normal control subjects, suggesting that these cells were comparable with circulating malignant cells [30]. CXCR4 was the predominant biomarker on pan-cytokeratin+ cells in the circulation of patients with metastatic RCC, suggesting that the presence of CXCR4 expression on these cells may directly correlate with metastatic RCC. Furthermore, we found that elevated co-expression of pan-cytokeratin and CXCR4 may be a prognostic marker for patients with advanced disease, as most patients in this study had stage III or IV lung cancer. Elevated co-expression of pan-cytokeratin and CXCR4 was significantly associated with poor survival in NSCLC.

CXCR4 may be important in our search to identify a biomarker or group of markers that offer the ability to detect micrometastatic disease in the blood before systemic recurrence or progression. A wide variety of biomarkers have been studied to this end, and implicated in determining prognosis for NSCLC. Thyroid transcription factor 1 (TTF1) is responsible for regulating gene tran- scription in the organogenesis of both thyroid and lung [31]. It has been an important marker in identifying primary lung cancers. TTF1 has been described as a potential prognostic marker associated with improved survival for patients with stage I adenocarcinoma of the lung [32]. Epithelial cellular adhesion molecule (Ep-CAM) has also been used to ascertain disseminated tumor cells in patients with surgically resectable NSCLC, and circulating levels have been associated with reduced disease-free survival $[33,34]$. A recent study by $Z$ hu et al developed immunomarker-support vector machines-based prognostic classifiers for stage IB NSCLC, which were associated with survival [35]. The models integrate age, cancer cell type and either 5 or 19 markers including, CD34MVD, p21ras, p21WAF, BCL2, caspase-9, low-molecular-weight cytokeratin, high-molecular-weight cytokeratin, cyclooxygenase-2, EMA, HER2, matrix metalloproteinases (MMP)2, MMP-9, p16, p27kip1, p53, vascular endothelial growth factor, $\beta$ - catenin, and tissue inhibitors of metalloproteinases (TIMP)-1 and TIMP-2. In another study, Nagrath et al identified a highly sensitive method to evaluate circulating tumor cells from blood samples, which may correlate with tumor response to therapy [36]. Exploring these markers and techniques may prove beneficial for detecting micrometastatic disease in NSCLC. Exploiting signaling pathways involved with associated markers may be important for inhibiting micrometastatic disease to improve outcomes.

The expression of CXCR4 and HIF- $1 \alpha$ have been linked in NSCLC [26]. Hypoxia and more specifically HIF-1 $\alpha$ has been found to be a critical transcription factor for gene expression of CXCR4 [37-39]. Moreover, VHL can negatively regulate the expression of CXCR4, owing to its capacity to target HIF- $1 \alpha$ for degradation under normoxic conditions $[37,38]$. This process may be suppressed under hypoxic conditions in cells allowing HIF-1 $\alpha$-dependent induction of CXCR4 expression $[37,38,40]$. These findings suggest that HIF-1 $\alpha /$ VHL may play a significant role in regulating the expression of CXCR4 on tumor cells, and further understanding this molecular mechanistic link between HIF-1 $\alpha$ and CXCR4 expression may allow the discovery of a novel means to intervene and impact on reducing metastatic NSCLC. SDF-1/CXCL12 is also regulated by HIF-1 in endothelial cells, increasing migration of circulating CXCR4-positive cells to areas of ischemic tissue. Blocking CXCL12 or CXCR4 inhibited the recruitment of these cells to sites of regenerating tissue [41]. Hypoxia, and particularly HIF- $1 \alpha$, has also been shown to regulate the expression of CXCR4 in cancer, including NSCLC $[38,40,42,43]$. Inhibition of chemokine signaling pathways with small molecule inhibitors has shown promise as a therapeutic option for regulating NSCLC growth and metastasis [26,44-46]. Further understanding of the mechanisms involved in CXCR4-mediated metasta- 
sis, and their interactions with other pathways important in NSCLC, may lead to more optimal therapeutic strategies in this disease.

\section{Conclusion}

These findings suggest that the CXCL12/CXCR4 biological axis may be a critical determinant for the metastatic potential of NSCLC. Therefore, further understanding the molecular mechanisms that are involved in the regulation of CXCR4 expression on tumor cells could lead to potential targets to modify the expression of CXCR4 and impact on metastases. Blocking these pathways may have a significant impact on the propensity for NSCLC to invade and metastasize and therefore, the future of treatment for the disease. In addition, delineation of how chemokine ligands and receptors modulate the malignant phenotype will provide novel insights into the pathogenesis of lung carcinoma. These results are not definitive, but hypothesis-generating. In future studies, we will prospectively evaluate the prognostic significance of pan-cytokeratin/ CXCR4-positive cells, and determine the mechanisms involved in the regulation of CXCR4 expression on tumor cells.

\section{Competing interests}

The authors declare that they have no competing interests.

\section{Authors' contributions}

KR participated in study conception, design, data acquisition, interpretation of data and drafting of the manuscript. RF participated in study design, data acquisition, and drafting of the manuscript. $\mathrm{MB}$ participated in data acquisition and analysis. SD participated in study conception, design and drafting of the manuscript. RE participated in data analysis. RS participated in study conception, design, interpretation of data and drafting of the manuscript. All authors read and approved the final manuscript.

\section{Acknowledgements}

We wish to thank Weiqing Liu for her assistance in preparing the manuscript. Supported by NIH P50CA90388 (klr; raf; mdb; smd; rme; rms), HL66027 and CA87879 (rms), the GLAVAHS Career Development Award and the Phase One Foundation (klr).

\section{References}

I. Jemal A, Siegel R, Ward E, Murray T, Xu J, Thun MJ: Cancer statistics, 2007. CA Cancer J Clin 2007, 57:43-66.

2. Winton T, Livingston R, Johnson D, Rigas J, Johnston M, Butts $C$, Cormier Y, Goss G, Inculet R, Vallieres E, et al.: Vinorelbine plus cisplatin vs. observation in resected non-small-cell lung cancer. N Engl J Med 2005, 352:2589-2597.

3. Arriagada R, Bergman B, Dunant A, Le Chevalier T, Pignon JP, Vansteenkiste J: Cisplatin-based adjuvant chemotherapy in patients with completely resected non-small-cell lung cancer. N Engl J Med 2004, 350:35I-360.

4. Kato $H$, Ichinose $Y$, Ohta M, Hata E, Tsubota N, Tada H, Watanabe $\mathrm{Y}$, Wada $\mathrm{H}$, Tsuboi M, Hamajima N, Ohta M: A randomized trial of adjuvant chemotherapy with uracil-tegafur for adenocarcinoma of the lung. N Engl J Med 2004, 350: I7I3-I72I.
5. Moss T], Sanders DG: Detection of neuroblastoma cells in blood. J Clin Oncol 1990, 8:736-740.

6. Gross HJ, Verwer B, Houck D, Hoffman RA, Recktenwald D: Model study detecting breast cancer cells in peripheral blood mononuclear cells at frequencies as low as $10(-7)$. Proc Natl Acad Sci USA 1995, 92:537-54|.

7. Peck K, Sher YP, Shih JY, Roffler SR, Wu CW, Yang PC: Detection and quantitation of circulating cancer cells in the peripheral blood of lung cancer patients. Cancer Res 1998, 58:276I-2765.

8. Ge M, Shi D, Wu Q, Wang M, Li L: Fluctuation of circulating tumor cells in patients with lung cancer by real-time fluorescent quantitative-PCR approach before and after radiotherapy. J Cancer Res Ther 2005, I:22I-226.

9. Burger JA, Kipps TJ: CXCR4: a key receptor in the crosstalk between tumor cells and their microenvironment. Blood 2006, 107:176I-1767.

10. Rollins BJ: Chemokines. Blood 1997, 90:909-928.

II. Baggiolini M, Dewald B, Moser B: Human chemokines: an update. Annu Rev Immunol 1997, 15:675-705.

12. Luster AD: Chemokines-chemotactic cytokines that mediate inflammation. $N$ Engl J Med 1998, 338:436-445.

13. Kakinuma T, Hwang ST: Chemokines, chemokine receptors, and cancer metastasis. J Leukoc Biol 2006, 79:639-65I.

14. Zlotnik A, Yoshie O: Chemokines: a new classification system and their role in immunity. Immunity $2000,12: 121-127$

15. Balkwill F: Cancer and the chemokine network. Nat Rev Cancer 2004, 4:540-550.

16. Muller A, Homey B, Soto H, Ge N, Catron D, Buchanan ME, McClanahan T, Murphy E, Yuan W, Wagner SN, et al: Involvement of chemokine receptors in breast cancer metastasis. Nature 200I, 4I 0:50-56.

17. Balkwill F: The significance of cancer cell expression of the chemokine receptor CXCR4. Semin Cancer Biol 2004, 14:17I-179.

18. Kucia M, Jankowski K, Reca R, Wysoczynski M, Bandura L, Allendorf DJ, Zhang J, Ratajczak J, Ratajczak MZ: CXCR4-SDF-I signalling, locomotion, chemotaxis and adhesion. I Mol Histol 2004, 35:233-245

19. Zlotnik A: Chemokines in neoplastic progression. Semin Cancer Biol 2004, | 4:18I-185.

20. Phillips RJ, Burdick MD, Lutz M, Belperio JA, Keane MP, Strieter RM: The stromal derived factor-I/CXCLI2-CXC chemokine receptor 4 biological axis in non-small cell lung cancer metastases. Am J Respir Crit Care Med 2003, 167:1676-1686.

21. Moepps B, Braun M, Knopfle K, Dillinger K, Knochel W, Gierschik P. Characterization of a Xenopus laevis CXC chemokine receptor 4: implications for hematopoietic cell development in the vertebrate embryo. Eur J Immunol 2000, 30:2924-2934.

22. Ma $\mathrm{Q}$, Jones $\mathrm{D}$, Springer TA: The chemokine receptor CXCR4 is required for the retention of $B$ lineage and granulocytic precursors within the bone marrow microenvironment. Immunity 1999, 10:463-47I.

23. Kucia M, Reca R, Miekus K, Wanzeck J, Wojakowski W, JanowskaWieczorek A, Ratajczak J, Ratajczak MZ: Trafficking of normal stem cells and metastasis of cancer stem cells involve similar mechanisms: pivotal role of the SDF-I-CXCR4 axis. Stem Cells 2005, 23:879-894

24. Phillips RJ, Burdick MD, Hong K, Lutz MA, Murray LA, Xue YY, Belperio JA, Keane MP, Strieter RM: Circulating fibrocytes traffic to the lungs in response to CXCLI 2 and mediate fibrosis. J Clin Invest 2004, I | 4:438-446.

25. Strieter RM: Chemokines: not just leukocyte chemoattractants in the promotion of cancer. Nat Immunol 200I, 2:285-286.

26. Phillips RJ, Mestas J, Gharaee-Kermani M, Burdick MD, Sica A, Belperio JA, Keane MP, Strieter RM: Epidermal growth factor and hypoxia-induced expression of CXC chemokine receptor 4 on non-small cell lung cancer cells is regulated by the phosphatidylinositol 3-kinase/PTEN/AKT/mammalian target of rapamycin signaling pathway and activation of hypoxia inducible factor-I alpha. J Biol Chem 2005, 280:22473-2248I.

27. Holland JD, Kochetkova M, Akekawatchai C, Dottore M, Lopez A, McColl SR: Differential functional activation of chemokine receptor CXCR4 is mediated by $\mathrm{G}$ proteins in breast cancer cells. Cancer Res 2006, 66:4117-4I24.

28. Su L, Zhang J, Xu H, Wang Y, Chu Y, Liu R, Xiong S: Differential expression of CXCR4 is associated with the metastatic 
potential of human non-small cell lung cancer cells. Clin Cancer Res 2005, I I:8273-8280.

29. Yoon Y, Liang Z, Zhang X, Choe M, Zhu A, Cho HT, Shin DM, Goodman MM, Chen ZG, Shim H: CXC chemokine receptor-4 antagonist blocks both growth of primary tumor and metastasis of head and neck cancer in xenograft mouse models. Cancer Res 2007, 67:75I8-7524.

30. Pan J, Mestas J, Burdick MD, Phillips RJ, Thomas GV, Reckamp K, Belperio JA, Strieter RM: Stromal derived factor-I (SDF-I/ CXCLI2) and CXCR4 in renal cell carcinoma metastasis. Mol Cancer 2006, 5:56.

31. Kimura S, Hara Y, Pineau T, Fernandez-Salguero P, Fox CH, Ward JM, Gonzalez FJ: The T/ebp null mouse: thyroid-specific enhancerbinding protein is essential for the organogenesis of the thyroid, lung, ventral forebrain, and pituitary. Genes Dev 1996, 10:60-69.

32. Anagnostou VK, Syrigos KN, Bepler G, Homer RJ, Rimm DL: Thyroid transcription factor $I$ is an independent prognostic factor for patients with stage I lung adenocarcinoma. J Clin Oncol 2009, 27:27I-278.

33. Sawabata $N$, Okumura M, Utsumi T, Inoue M, Shiono H, Minami M, Nishida T, Sawa Y: Circulating tumor cells in peripheral blood caused by surgical manipulation of non-small-cell lung cancer: pilot study using an immunocytology method. Gen Thorac Cardiovasc Surg 2007, 55:189-192.

34. Kubuschok B, Passlick B, Izbicki JR, Thetter O, Pantel K: Disseminated tumor cells in lymph nodes as a determinant for survival in surgically resected non-small-cell lung cancer. J Clin Oncol 1999, 17:19-24.

35. Zhu ZH, Sun BY, Ma Y, Shao JY, Long H, Zhang X, Fu JH, Zhang LJ, Su $\mathrm{XD}, \mathrm{Wu} \mathrm{QL}$, et al.: Three immunomarker support vector machines-based prognostic classifiers for stage IB non-smallcell lung cancer. J Clin Oncol 2009, 27:1091-1099.

36. Nagrath S, Sequist LV, Maheswaran S, Bell DW, Irimia D, Ulkus L, Smith MR, Kwak EL, Digumarthy S, Muzikansky A, et al.: Isolation of rare circulating tumour cells in cancer patients by microchip technology. Nature 2007, 450:1235-I 239.

37. Schioppa T, Uranchimeg B, Saccani A, Biswas SK, Doni A, Rapisarda A, Bernasconi S, Saccani S, Nebuloni M, Vago L, et al:: Regulation of the chemokine receptor CXCR4 by hypoxia Chemokine receptor CXCR4 downregulated by von Hippel-Lindau tumour suppressor pVHL. JExp Med 2003, | 98:|39|-| 402.

38. Staller P, Sulitkova J, Lisztwan J, Moch H, Oakeley EJ, Krek W: Chemokine receptor CXCR4 downregulated by von Hippel-Lindau tumour suppressor pVHL. Nature 2003, 425:307-3II.

39. Pantuck AJ, Zeng G, Belldegrun AS, Figlin RA: Pathobiology, prognosis, and targeted therapy for renal cell carcinoma: exploiting the hypoxia-induced pathway. Clin Cancer Res 2003, 9:464I-4652

40. Liu YL, Yu JM, Song XR, Wang XW, Xing LG, Gao BB: Regulation of the chemokine receptor CXCR4 and metastasis by hypoxia-inducible factor in non small cell lung cancer cell lines. Cancer Biol Ther 2006, 5:1320-1326.

4I. Ceradini DJ, Kulkarni AR, Callaghan MJ, Tepper OM, Bastidas N Kleinman ME, Capla JM, Galiano RD, Levine JP, Gurtner GC: Progenitor cell trafficking is regulated by hypoxic gradients through HIF-I induction of SDF-I. Nat Med 2004, 10:858-864.

42. Schioppa T, Uranchimeg B, Saccani A, Biswas SK, Doni A, Rapisarda A, Bernasconi S, Saccani S, Nebuloni M, Vago L, et al.: Regulation of the chemokine receptor CXCR4 by hypoxia. J Exp Med 2003, 198: $1391-1402$.

43. Zagzag D, Krishnamachary B, Yee H, Okuyama $\mathrm{H}$, Chiriboga L, Ali MA, Melamed J, Semenza GL: Stromal cell-derived factor-I alpha and CXCR4 expression in hemangioblastoma and clear cellrenal cell carcinoma: von Hippel-Lindau loss-of-function induces expression of a ligand and its receptor. Cancer Res 2005, 65:6|78-6188.

44. Hudes G, Carducci M, Tomczak P, Dutcher J, Figlin R, Kapoor A, Staroslawska E, Sosman J, McDermott D, Bodrogi I, et al.: Temsirolimus, interferon alfa, or both for advanced renal-cell carcinoma. N Engl J Med 2007, 356:227I-228I.

45. Shepherd FA, Rodrigues Pereira J, Ciuleanu T, Tan EH, Hirsh V, Thongprasert S, Campos D, Maoleekoonpiroj S, Smylie M, Martins R, et al:: Erlotinib in previously treated non-small-cell lung cancer. N Engl ] Med 2005, 353:123-132.
46. Granville CA, Warfel N, Tsurutani J, Hollander MC, Robertson M, Fox SD, Veenstra TD, Issaq HJ, Linnoila RI, Dennis PA: Identification of a highly effective rapamycin schedule that markedly reduces the size, multiplicity, and phenotypic progression of tobacco carcinogen-induced murine lung tumors. Clin Cancer Res 2007, 13:228I-2289.

\section{Pre-publication history}

The pre-publication history for this paper can be accessed here:

http://www.biomedcentral.com/1471-2407/9/213/pre pub

Publish with Bio Med Central and every scientist can read your work free of charge

"BioMed Central will be the most significant development for disseminating the results of biomedical research in our lifetime. "

Sir Paul Nurse, Cancer Research UK

Your research papers will be:

- available free of charge to the entire biomedical community

- peer reviewed and published immediately upon acceptance

- cited in PubMed and archived on PubMed Central

- yours - you keep the copyright 